\title{
THE ISSUES OF CLASSIFICATION CRITERIA FOR THE CONVENTIONS AND RECOMMENDATIONS OF THE ILO
}

Makhmud Makhamatov

PhD student at the University of World Economy and Diplomacy, Republic of Uzbekistan

ORCID iD 0000-0002-0791-3027

\section{Crossref}

Issue DOI http://dx.doi.org/10.26739/2433-202x-2017-10-10

Article DOI http://dx.doi.org/10.26739/2433-202x-2017-10-10-3

\section{ABSTRACT}

The paper analyzes the classification of international documents adopted by the International Labor Organization based on specific criteria. Analyzed accepted criteria by local and foreign scientists in the classification of ILO documents, as well as proposed which types of ILO documents should be classified and based on which criterion.

Keywords: international document, international treaty, convention, recommendation, declaration, resolution, protocol, International Labor Organization, classification, criteria, and ratification. 
In the course of the age-old activity of the International Labor Organization (ILO), almost in all provisions concerning labour, which is one of the most important parts of the social sphere, have been developed and adopted acts in the form of conventions and recommendations. The period of the adoption of these international legal instruments (1919-2017), and their huge number (189 conventions, 205 recommendations), as well as their content lead to the need for their classification based on certain criteria. The classification of any international legal instrument is important for understanding its essence and for a deeper study of its legal nature. Here, one cannot but agree with the opinion of the researchers of the ILO conventions and recommendations K.Gusova and V.Tolkunova: "Classification of ILO conventions and recommendations on labor as a source of international labor law is not any distribution of them into groups, but unification on the basis of objectively existing and justified in scientific plan criteria (the basis of such classification)"1.

Summing up the opinions expressed by the researchers who studied norm-setting activities of the ILO, scientists can be divided into following two groups:

The first group: the subject and the form of regulation of documents that consider the main criterion;

The second group: considering the criterion of the scope of obligations in the acts and their relevance in this period.

It is also noteworthy to mention the criteria for the classification of the conventions and recommendations of the ILO proposed by K.Gusov and V.Tolkunova based on the following criteria:

1) the form of expression of international labor standards;

2) the way of applying to the regulation of labor relations;

3 ) the contingent of the workers in whom they are calculated;

4) the object of regulation ${ }^{2}$.

The classification criteria proposed by N.Liutov and P.Morozov - the authors of the textbook "International Labor Law" - not only complement the above criteria, but also try to embrace other documents of the ILO, in addition to its conventions and recommendations.

In particular, they are examined by such criteria as:

a) on the status of documents; b) on the content of documents; c) other criteria for the classification of documents ${ }^{3}$. When covering other criteria, they

\footnotetext{
${ }^{1}$ Gusov K.N., Tolkunova V.N. Labour law of Russia: manual. - M., 2004. - P. 462.

${ }^{2}$ Gusov K.N., Tolkunova V.N. Labour law of Russia: manual. - M., 2004. - P. 463.

${ }^{3}$ Lutov N.L., Morozov P.E. International labour law: manual. - M., 2011. - P. 38-44.

Social science and humanities
} 
expressed their opinion on the four categories proposed by K.Gusov and V.Tolkunova. At the same time, in the classification of documents of the ILO, the following documents are taken into account in their form: conventions and protocols to them, recommendations, declarations, resolutions of the International Labor Conference (ILC), principles of freedom of association.

If we take into account a variety of approaches and the absence of specific conclusions on their justification ${ }^{4}$, in our opinion, in order to classify the documents of the ILO the criterion of classifications is expedient to be divided into 2 criteria:

- main criterion;

- additional criterion.

When classifying according to the main criterion, attention is paid to the relative stability of the classification of documents, the lack of dependence on specific periodic features and decrees and decisions of the authorized bodies. Additional classifications can be conducted in the sphere of classification carried out according to the main criterion. Classification of the status of acts will be more appropriately carried out as an additional criterion. First, the classification by status is variable and can change from time to time based on the decisions of the relevant authorities; secondly, the definition of the status of the documents should be made only by official authorized bodies.

Scientists N.Valtikos and J.Potobsky, who scrutinized international labor standards, ILO documents, based on the subject of conventions and recommendations, classified and defined 16 types of international labor standards ${ }^{5}$.

We cannot agree with the statement of the researcher of international labor standards, V. Leri, who believes that "ILO conventions can be classified on the basis of the characteristics defined in their obligations" and divides them into 3 groups: 1 ) reflecting the obligations of states; 2 ) requiring specific actions; 3) making up a small number of encouraging conventions ${ }^{6}$. Since, in international treaties, including in ILO conventions, to achieve the objectives of the treaty, although various states rely on them, they will not be sufficient for a full presentation of the essence-content, the system of conventions. Therefore, it is expedient to study and analyze proceeding from a subject of regulation, instead of obligations of the states.

\footnotetext{
${ }^{4}$ Morozov P.E. The classification problems of International labour law sources in the context of globalization. // Business in law, №5, 2011. - P. 151.

${ }^{5}$ Valticos N. Potobsky G. International Labour Law, 1994. P. 7-13.

${ }^{6}$ Leary V. "Form Follows Function" - Or Does it? Formulations of International Labour Standards: Treaties, Codes, Soft Law, Trade Agreements. Stanford Law School International Standards Conference. May 2002. P. 8.
}

Social science and humanities

M.Makhamatov 
The definition in the ILO Declaration on Fundamental Principles and Rights at Work adopted in 1998 there is a classification of ILO documents. Specifically, it "declares that all Members, even if they have not ratified the Conventions in question, have an obligation arising from the very fact of membership in the Organization to respect, to promote and to realize, in good faith and in accordance with the Constitution, the principles concerning the fundamental rights which are the subject of those Conventions, namely:

(a) freedom of association and the effective recognition of the right to collective bargaining;

(b) the elimination of all forms of forced or compulsory labour;

(c) the effective abolition of child labour; and

(d) the elimination of discrimination in respect of employment and occupation"7.

L.A.Kostin, although he did not carry out a separate ILO classification, explained in his works, through the Organization's conventions and recommendations, the main directions of the ILO's activities. The scientist singled out 12 main directions of the ILO's activity ${ }^{8}$.

It is worth to support the opinion of the scientist O.V.Glikman, who investigated the problem of protecting human's labour rights at the current stage of the ILO activity, which considers necessary classification on the basis of the subject of legal regulation and take into account the actual significance of these documents 9 .

The classification of the ILO conventions by the staff of the International Labor Office (ILO), on the basis of this criterion, again indicates its practical importance. With this classification of conventions, the ILO, on the basis of the subject of regulation, is divided into 23 groups and the conventions within each group are classified according to their status.

The exceptional side of this classification from earlier actions is its peculiarity in that, firstly, it is executed on the basis of the subject of regulation of conventions and recommendations; secondly, the conventions and recommendations included in each group on the basis of the conclusion of the authorized bodies are divided into documents based on their status; thirdly, the fundamental conventions are listed separately.

Classification of ILO acts was of interest not only to foreign scientists, but also to Uzbek researchers and scientists. In the collection titled

\footnotetext{
7 ILO Declaration on fundamental principles and rights at work. www.ilo.org/declaration. CIT/1998/PR20A

${ }^{8}$ Kostin L.A. International labour law. - M. 2002. - P. 3-4.

${ }^{9}$ Glyckman O.V. Protection of human rights at work in the ILO's activity at the current stage. Abstract of PhD thesis . 12.00.10 - International Law; European law. - M., 2004.
}

Social science and humanities 
"Conventions and Recommendations of the International Labor Organization", published under the responsible editorship of Professor A.Kh. Saidov, 29 documents of the ILO are contained and they are given on their status in the following order:

- ILO Core Conventions;

- ILO Conventions of particular importance;

- Recommendations relevant to the main ILO convention:

- ILO recommendations on the recognition in practice of the right to freedom of association and collective bargaining;

- ILO recommendations on the prevention of all forms of forced and compulsory labor;

- ILO recommendations on the definitive prohibition of child labor;

- ILO recommendations on the prevention of discrimination in the world of work and types of work;

- some conventions and recommendations of the ILO.

The views of Professor A.Kh.Saidov on the classification of conventions and ILO recommendations are worthy of attention. In his opinion, ILO acts are classified according to their content in the following order: 1) documents on basic human rights and freedoms; 2) documents on the provision of work and protection against unemployment; 3) documents regulating working conditions; 4) documents on the safety of industrial sanitation; 5) documents on legal protection to a higher degree of separate groups of workers; 6) documents on cooperation of the state, employers and organization of labor disputes by peaceful means ${ }^{10}$.

Prior to this, when classifying conventions and recommendations for the use of their content as a criterion was not met. In addition, it is possible to continue the classification of all ILO conventions and recommendations on this criterion.

Proceeding from the foregoing, the following criteria for the classification of adopted ILO documents are proposed:

first, in the form of the expression of international labor standards: a convention, a protocol, a recommendation, a declaration;

secondly, on the object of legal regulation (additionally classify the acts in the composition of each subject according to their current status);

thirdly, in the field of legal regulation: general and special.

In our opinion, the main criterion for classifying documents adopted by the ILO should be their content and the subject of regulation.

\footnotetext{
${ }^{10}$ Conventions and recommendations of the International Labor Organization. / Executive ed. A.Kh.Saidov. - T.: The National Human Rights Center of the Republic of Uzbekistan, 2008. - P. 3-4.

Social science and humanities

M.Makhamatov
} 
It is advisable to bring not only the conventions, but also the recommendations adopted according to them. On some issues a convention as well as a recommendation were adopted, but in some cases only a recommendation was drafted. The division of the conventions and recommendations adopted for each subject into two groups: open for ratification and closed for ratification will give an opportunity to analyze to what extent ILO documents meet the requirements of today, how legal relations are effectively regulated.

So, the classification of international legal acts carried out by scientists and researchers, although informal, is of great practical importance in systematization and codification, studying the tendency of ratification of these conventions by states. 